DOI: https://doi.org/10.12797/Politeja.15.2018.54.13

\author{
Marcin GALENT \\ Uniwersytet Jagielloński \\ m.galent@uj.edu.pl
}

\title{
KRYZYS SYSTEMOWY STREFY EURO W CIENIU TRAKTATU Z MAASTRICHT I TRAKTATU Z LIZBONY
}

\section{ABSTRACT The Eurozone Crisis in the Shade of the Maastricht and Lisbon Treaties} The financial crisis in the eurozone has created a kind of discursive window through which a renewed self-reflection on the shape on the European integration can be traced. The crisis, its depth and course, has confirmed what previously could only be speculated on the edge of European discourse, namely the fact that the chosen model of deepening the economic and monetary union is not ideologically and class neutral. It therefore generates new decisive conditions about who becomes the beneficiary and the loser, where new centres and peripheries crystallize in this process. The purpose of this article is to use the crisis in the euro area to look at its structure, identify the most important intellectual and ideological assumptions underlying it, indicate how the legal framework contained in the Maastricht and Lisbon Treaties influenced its course and who and why suffered the most losses. Finally, the task of the article is to determine which aspects of the architecture of the eurozone proved to be unsustainable and what has therefore had to be changed in it.

Keywords: crisis, eurozone, macroeconomy, European integration

Słowa kluczowe: kryzys, strefa euro, makroekonomia, integracja europejska 


\section{WSTĘP}

Pierwsze znane użycia słowa „kryzys” przypisuje się starożytnym greckim medykom: Hipokratesowi i Galenowi, którzy określali nim moment zwrotu w chorobie. Chory pacjent wchodził w stadium, w którym różne objawy się nasilały, a po ich szczytowym natężeniu choroba albo się wycofywała i pacjent wracał do zdrowia, albo wzmacniała i bezbronny pacjent umierał. Słowo to zostało później zlatynizowane, a w średniowieczu trafiło do języka angielskiego, w którym rozszerzyło swoje pole semantyczne i zaczęło funkcjonować poza obszarem medycyny. Zachowało jednak część pierwotnego znaczenia, odnosząc się do punktu zwrotnego lub decydującego. Kryzys miał opisywać sytuację, w której po okresie próby, badania i oceniania nadchodził moment podjęcia decyzji. Trzeba było uznać, że w trakcie trwania danego procesu pojawiło się wystarczająco dużo przesłanek do jego zakończenia, radykalnej zmiany lub kontynuacji. Kryzys wiąże się więc również ze zdolnością do oceny, umiejętnością oddzielenia elementów pożądanych od niepożądanych, możliwością dokonania wyboru i akceptacji tego, co jest uznawane za słuszne, oraz odrzucenia tego, co szkodliwe i niebezpieczne. Kryzys jest zatem swojego rodzaju oknem dyskursywnym, dzięki któremu może dojść do odnowionej autorefleksji wytyczającej drogi do zaktywizowanej podmiotowości społecznej.

Kryzys systemowy strefy euro, jego głębokość i przebieg potwierdziły to, o czym wcześniej można było tylko spekulować na obrzeżach europejskiego dyskursu: fakt, że wybrany model pogłębiania unii gospodarczo-walutowej nie jest neutralny ideologicznie i klasowo, zatem generuje nowe warunki decydujące o tym, kto zostaje beneficjentem i przegranym, gdzie krystalizują się nowe centra i peryferie tego procesu. W niniejszym artykule kryzys strefy euro jest przesłanką do oceny prawidłowości jej konstrukcji, zidentyfikowania najważniejszych założeń intelektualnych i ideologicznych leżących u podstaw jej architektury, a także wskazania, w jaki sposób ramy prawne zawarte w traktatach z Maastricht i Lizbony wpłynęly na sam kryzys. Celem artykułu jest ustalenie, które aspekty architektury strefy euro okazały się nie do utrzymania i co w związku z tym się w niej zmieniło.

\section{PIERWSZE PRZYMIARKI}

Chociaż wspólna waluta została wprowadzona mocą traktatu z Maastricht przyjętego w 1992 r., plany jej wprowadzenia pojawiały się znacznie wcześniej. Warto do nich wrócić, ponieważ dają one dobry wgląd w zmieniające się paradygmaty ekonomiczne i konteksty ideologiczne, na gruncie których wypracowano później konkretne rozwiązania.

Pierwsze praktyczne przesłanki do ustanowienia wspólnej waluty europejskiej zostały zawarte w tzw. raporcie Wernera. W 1969 r. na szczycie europejskim w Hadze powołano grupę polityków i ekspertów wysokiego szczebla, na czele której stanął premier i minister finansów Luksemburga Pierre Werner. Zadaniem grupy było przygotowanie 
raportu w sprawie możliwości dokończenia budowania unii gospodarczo-walutowej, której ostatecznym celem miała się stać wspólna waluta. Raport przedstawiono w 1970 r., ale nigdy nie stał się podstawą do politycznego działania. Zadecydowała o tym dekada światowego kryzysu związana z upadkiem systemu z Bretton Woods, szokami naftowymi i gwałtownym wzrostem inflacji w świecie Zachodu, a także w dużym stopniu niechęć Francuzów do wzmacniania wymiaru supranarodowego w Europie ${ }^{1}$.

Z perspektywy niniejszego artykułu ważne jest jednak to, w jaki sposób wyobrażano sobie dobrze działającą unię walutową, jakie mechanizmy ekonomiczne i polityczne miały zapewnić skuteczność i bezpieczeństwo jej funkcjonowania. Trzeba podkreślić, że ów plan dokończenia budowy unii gospodarczo-walutowej zdecydowanie różnił się od traktatu z Maastricht, czyli umowy, na podstawie której ostatecznie ją zrealizowano. Różnica polegała przede wszystkim na tym, że w planie Wernera nie wyobrażano sobie wprowadzenia unii walutowej bez równoległego zbudowania silnych elementów unii politycznej. Zakładano w nim, że transfer na poziom Wspólnot wtadzy sprawowanej do tej pory przez wtadze narodowe zajdzie równolegle z odpowiednim transferem parlamentarnej odpowiedzialności z ptaszczyzny narodowej na ptaszczyznę Wspólnot. Centrum decyzji w zakresie polityki ekonomicznej będzie politycznie odpowiedzialne przed Parlamentem Europejskim ${ }^{2}$. Jak podkreśla wielu badaczy, elementy unii politycznej można odnaleźć na wielu poziomach. Raport zakłada np., że: krótkoterminowa polityka ekonomiczna będzie prowadzona w planie ogólnym na poziomie Wspólnot; zasadnicze decyzje polityki pieniężnej będą scentralizowane; ponieważ budżet wspólnotowy będzie niewystarczający do efektywnego oddziaływania na gospodarkę, niezbędne stanie się wypracowanie narzędzi do wywierania wpływu na budżety narodowe, szczególnie w przypadku pojawienia się deficytów i nadwyżek budżetowych; makroekonomiczna nierównowaga znajdzie się w kompetencji centralnych władz Wspólnoty odpowiedzialnych przed Parlamentem Europejskim ${ }^{3}$.

W planie Wernera wspólna waluta jest zatem pomyślana jako integralna część wspólnej polityki gospodarczej, zdolnej do zarządzania i przeciwdziałania asymetrycznym napięciom i nierównowagom, które nieubłaganie pojawiają się w obrębie każdej gospodarki. Polityka fiskalna została w nim uznana za nadrzędną wobec monetarnej. Wyraźnie podkreślono również odpowiedzialność Wspólnot i jej władz za wzrost gospodarczy i zatrudnienie, osiągane przez odpowiednią prowadzoną politykę przeciwcykliczną w całej strefie walutowej. W raporcie nie ma mowy o apolitycznym i niezależnym banku centralnym, który nie ponosi odpowiedzialności za stan gospodarki i którego nadrzędnym celem jest dbanie jedynie o stabilność cen ${ }^{4}$.

W. Mitchell, Eurozone Dystopia. Groupthink and Denial on a Grand Scale, Cheltenham-Northampton 2015, s. 37-45.

2 European Commission, Report to the Council and the Commission on the Realization by Stages of Economic and Monetary Union in the Community [Raport Wernera], 1970, s. 13, [online] http://ec.europa.eu/economy_finance/publications/pages/publication6142_en.pdf, 12 II 2018.

3 Tamże, s. 10-12.

4 W. Mitchell, T. Fazi, Reclaiming the State. A Progressive Vision of Sovereignty for a Post-Neoliberal World, London 2017, s. 87-92. 
Kolejna przymiarka do zacieśniania unii gospodarczo-walutowej i wprowadzenia wspólnej waluty zaprezentowana została w tzw. raporcie MacDougalla w 1977 r. W 1974 r. Komisja Europejska zleciła grupie niezależnych ekspertów sporządzenie raportu, którego celem miało być określenie roli finansów publicznych w dalszym zacieśnianiu integracji europejskiej. W skład zespołu wchodziło ośmiu wybitnych profesorów ekonomii z kilku europejskich krajów oraz po jednym z Australii i z USA. Na czele grupy stanął Donald MacDougall, były wpływowy doradca ekonomiczny kilku brytyjskich rządów, zarówno konserwatywnych, jak i lewicowych, wykładowca Uniwersytetu Oksfordzkiego 5 . Raport liczył sobie dwa tomy i wyczerpująco odnosił się do różnych wymiarów unii gospodarczej.

Nie ma tu powodu, aby poruszać większość zawartych w nim wątków. Trzeba jednak podkreślić, że - podobnie jak w raporcie Wernera - za najważniejszą uznawana jest tutaj aktywna i interweniująca scentralizowana polityka gospodarcza, której rolą byłoby ograniczanie negatywnych konsekwencji wynikających z wprowadzenia wspólnej waluty. Głównym narzędziem takich interwencji miała być polityka fiskalna oparta na wspólnym europejskim budżecie. Na wzór innych federacji, np. niemieckiej czy amerykańskiej, interweniowałby on w celu łagodzenia napięć gospodarczych i przeciwdziałałby regionalnym spadkom poziomu życia. Raport zakładał, że w dalekiej przyszłości, kiedy doszłoby do zaawansowanej federalizacji Wspólnot Europejskich, wysokość transferów fiskalnych mogłaby się zbliżać do poziomu notowanego w owych czasach w USA i RFN, czyli do $25 \%$ produktu krajowego brutto (PKB). Zaleceniem raportu było rozpoczęcie budowy prawdziwej unii gospodarczo-walutowej od ustanowienia budżetu w wysokości 2-2,5\% PKB, by następnie, po wprowadzeniu wspólnej waluty, zwiększyć go do co najmniej 5-7\%, a nawet 7,5-10\%, jeśli miałyby w to być wliczone wydatki na obronność. Zdaniem autorów raportu, takie rozwiązanie mogtoby zapewnić wtaściwe geograficzne wyrównanie produktywności, standardów życiowych i neutralizacje przejsciowych fluktuacji $w$ celu wsparcia unii walutowej ${ }^{6}$. Do stworzenia stabilnej unii walutowej niezbędne były więc wspólne narzędzia podatkowe zdolne do odpowiedniego zasilania scentralizowanego budżetu.

Widać zatem wyraźnie, że - tak jak w przypadku propozycji zawartych w raporcie Wernera - rozwiązania przygotowane przez zespół MacDougalla uwzględniały jakiś rodzaj unii politycznej. Decydowanie o tak wysokich transferach finansowych pomiędzy różnymi obszarami wspólnej waluty wymagałoby bowiem rozstrzygnięć politycznych w oparciu o demokratyczną reprezentację, legitymizację i odpowiedzialność.

Ostatecznie plan ten nie zyskał poparcia politycznego i propozycja została odłożona na półkę. Sam MacDougall jeszcze wiele razy zabierał publicznie głos na temat wspólnej europejskiej waluty. Jego ostatnia interwencja pochodzi z 2000 r., kiedy

M. Posner, Sir Donald MacDougall. Government economic adviser from Churchill to Heath, „The Guardian" 2004, 25 III, [online] https://www.theguardian.com/news/2004/mar/25/guardianobituaries.obituaries, 10 III 2018.

6 European Commission, Report of the Study Group on the Role of Public Finance [Raport MacDougalla], Brussels 1977, s. 13-14, [online] http://ec.europa.eu/archives/emu_history/documentation/ chapter8/19770401en73macdougallrepvol1.pdf, 5 III 2018. 
przestrzegał, że strefa euro powstała w ramach traktatu z Maastricht nie spełni pokładanych w niej oczekiwań i jest skazana na nieuchronną porażkę7.

\section{IDEA WCIELONA W ŻYCIE. TRAKTAT Z MAASTRICHT}

Trzecie, zakończone sukcesem podejście do wprowadzenia wspólnej waluty rozpoczęło się w drugiej połowie lat $80 . \mathrm{XX}$ w. pod egidą Francji i Niemiec. Od tych dwóch aktorów zależały najważniejsze ekonomiczne i ideologiczne przesłanki wspólnej waluty, a te od czasu planu Wernera i raportu MacDougalla zmieniły się fundamentalnie. Między latami 70. i 80. XX w. zaszła bowiem paradygmatyczna rewolucja w ekonomii i polityce gospodarczej. W ciągu niespełna dekady zdyskredytowano dominujący model relacji pomiędzy gospodarką a społeczeństwem, wypracowany po wielkim kryzysie głównie na podstawie teorii ekonomicznej Johna Maynarda Keynesa, a jego miejsce zajął nowy paradygmat ekonomiczny, oparty przede wszystkim na dorobku monetarystów oraz zwolenników leseferyzmu, sprzeciwiających się ingerencji państwa w spontaniczne procesy gospodarcze. Wspólnym mianownikiem nowej polityki gospodarczej, określanej często mianem neoliberalizmu, były dwa elementy. Pierwszy to dążenie do maksymalnej dyscypliny fiskalnej, polegającej na traktowaniu zrównoważonego budżetu jako oznaki gospodarczego zdrowia, oraz maksymalnej dyscypliny monetarnej, realizowanej przez uniezależnienie banków centralnych od wpływów politycznych. Drugim elementem była prywatyzacja gospodarki i sektora publicznego, co miało się przełożyć na wzrost konkurencyjności i produktywności. Prywatyzacja, deregulacja i wolny rynek stały się kanonem obowiązującym w kręgach wszystkich ekonomicznych instancji mających jakikolwiek wpływ na władze w świecie Zachodu. Nie znaczy to oczywiście, że reprezentanci tej szkoły podzielali wszystkie poglądy na temat integracji europejskiej. Friedrich August von Hayek popierał integrację europejską, mając nadzieję, że będzie ona automatycznie ograniczała interwencjonizm państwowy ${ }^{8}$, k kolei Milton Friedman twierdził, że jeśli w miejsce możliwości dewaluacji walut nie pojawi się inny potężny mechanizm amortyzacyjny, to wspólna europejska waluta doprowadzi w Europie do załamania politycznej jedności?

Ten konsensus - nazwany później waszyngtońskim, bo wspierany i propagowany przez rząd amerykański, Międzynarodowy Fundusz Walutowy i Bank Światowy - przyjął się również w Europie kontynentalnej. W dużej mierze zdecydował o tym model gospodarki niemieckiej, określanej mianem ordoliberalizmu. Ład społeczno-gospodarczy

L. Halligan, Chronicle of a Disaster Foretold Plays Out on the Streets of Athens, „The Daily Telegraph” 2010, 1 V, [online] https://www.telegraph.co.uk/finance/comment/7664328/Chronicle-of-a-disaster-foretold-plays-out-on-the-streets-of-Athens.html, 10 III 2018.

8 F.A. Hayek, The Economic Conditions of Interstate Federalism, [w: Individualism and Economic Order, red. F.A. Hayek, Chicago 1948, s. 255-272.

9 M. Friedman, The Euro: Monetary Unity to Political Disunity?, „Project Syndicate” 1997, 28 IX, [online] https://www.project-syndicate.org/commentary/the-euro--monetary-unity-to-political-disunity, 8 II 2018. 
przyjęty w Niemczech po II wojnie światowej zawierał już podstawową ideę monetaryzmu, czyli dyscyplinę finansową. Hiperinflacja, której Niemcy doświadczyły w latach 20. XX w., była dla nich tak traumatycznym doświadczeniem, że z niezależności banku centralnego i stabilności pieniądza politycy i społeczeństwo niemieckie uczynili zasadę nadrzędną ${ }^{10}$. W przeciwieństwie do większości krajów Zachodu, nieufnie podchodzili oni również do instrumentów polityki gospodarczej opartej na ideach Keynesa. Chociaż nie były im one zupełnie obce i nawet aplikowano je za czasów rządów Willy’ego Brandta ${ }^{11}$, tuż po wojnie interwencja gospodarcza za bardzo kojarzyła się z polityką Hitlera $^{12}$.

Zupełnie inaczej wyglądała sytuacja we Francji, gdzie zwycięstwo pierwszego socjalistycznego premiera w V Republice w 1981 r. miało uczynić z tego kraju bastion oporu wobec wolnorynkowej globalizacji forsowanej przez świat anglosaski. Opór Francuzów nie trwał jednak długo. W 1983 r. francuski rząd stanął przed egzystencjalnym wyborem: mógł trzymać się lewicowego programu wyborczego gwarantującego wysoki wzrost gospodarczy i zatrudnienie, opartego na keynesizmie, a konkretnie na dopuszczaniu do występowania inflacji połączonej z kontrolą przepływu kapitału, co jednak wiązałoby się z porzuceniem Europejskiego Systemu Monetarnego (ESM), albo pozostać w nim i porzucić politykę realizowania keynesizmu. Francuski prezydent przyznał: Jestem rozdarty pomiędzy dwiema ambicjami: zbudowaniem Europy i realizacja sprawiedliwości spotecznej. ESM jest niezbędny dla tego pierwszego, ale jednocześnie ogranicza moje możliwości $w$ realizacji tego drugiego ${ }^{13}$. Ostatecznie François Mitterrand, za radą swojego byłego ministra finansów, gospodarki i budżetu Jacques’a Delorsa, wybrał budowę Europy. Francja uznała więc prymat rozwiązań neoliberalnych w zacieśnianiu europejskiej integracji ${ }^{14}$.

Wkrótce potem skończyła się cała powojenna epoka, rozpadł się blok radziecki i załamał dwubiegunowy porządek świata. Europejczycy zaczęli szukać w Europie swojego miejsca, znacznie bardziej podmiotowego niż w czasach zimnej wojny. Francuzi zdali sobie sprawę, że zjednoczone Niemcy mogą na nowo zdestabilizować równowagę na kontynencie, dlatego zdecydowanie ruszyli do budowania jeszcze ściślejszej unii. Ich celem było zeuropeizowanie Niemiec i zakotwiczenie ich w europejskim projekcie poprzez wspólną walutę. Wspólnym celem Niemców i Francuzów było zaś rzucenie wyzwania Amerykanom, a właściwie ich przesadnemu przywilejowi, którym cieszyli się w związku ze statusem dolara - światowej waluty rozliczeniowej. Wspólna waluta europejska miała stać się dla niego realną konkurencją ${ }^{15}$.

10 M.K. Brunnermeier, H. James, J.-P. Landau, The Euro and the Battle of Ideas, Princeton 2016.

11 W. Mitchell, Eurozone Dystopia..., s. 69.

12 M.K. Brunnermeier, H. James, J.-P. Landau, The Euro...

13 Za: T.B. Smith, France in Crisis, Welfare, Inequality, and Globalization since 1980, Cambridge-New York 2004, s. 89.

14 Monetary Union in Crisis. The European Union as Neo-Liberal Construction, red. B. Moss, Houndmills-New York 2004.

15 D. Marsch, The Euro. The Battle for the New Global Currency, Yale 2011. 
Tempo i skala wydarzeń tłumaczą zapewne wątłą refleksję intelektualną poprzedzającą wprowadzenie euro. Według Charlesa Wyplosza w sytuacji niewielkiego doświadczenia i teoretycznego zaplecza, ekonomiści i polityczni decydenci musieli wypracować niemal wszystko w bardzo krótkim czasie. Ci ostatni pospieszyli negocjować szczegótowe porozumienie, nie mając w ogóle czasu na pogtębione ekonomiczne analizy ${ }^{16}$.

Podstawą planu Delorsa, czyli budowy unii walutowej, stał się opublikowany przez Komisję Europejską raport zatytułowany One Market, One Money ${ }^{17}$. Odzwierciedla on zwrot $\mathrm{w}$ stronę zwalczania inflacji jako najważniejszego zadania polityki ekonomicznej, odsuwając na dalszy plan zmartwienia związane z dbaniem o właściwą dynamikę wzrostu gospodarczego i ograniczaniem bezrobocia. W przeciwieństwie do dwóch poprzednich raportów, nowa wizja wspólnej waluty odrzucała konieczność posiadania właściwego zabezpieczenia w postaci dużego wspólnego budżetu, zarządzanego na poziomie wspólnotowym przy demokratycznej kontroli. Architektura strefy euro miała być podporządkowana dwóm nadrzędnym celom: gwarancji stabilności cen, nad którą miał czuwać nowy wspólnotowy bank centralny, wyjęty spod demokratycznej kontroli i odpowiedzialności, oraz ścisłej kontroli finansów publicznych, które miały zostać poddane wspólnym regułom. Tym sposobem wizja architektury strefy euro została zdominowana przez jeden konkretny paradygmat ekonomiczny, który co prawda święcił tryumfy jako teoria w świecie akademickim i eksperckim, ale nie posiadał mocnych podstaw empirycznych.

Odpowiedzialny za przygotowanie konkretnego planu działań Jacques Delors świadomie zmierzał do ograniczenia szerszej debaty. Powołując komisję ekspertów, na czele której stanął osobiście, zrobił wszystko, żeby ją maksymalnie odpolitycznić i intelektualnie odideologizować. Wyłączył z niej ministrów finansów poszczególnych krajów członkowskich, a na ich miejsce zaprosił do pracy prezesów banków centralnych. Ci ostatni niemal co do jednego skłaniali się do przyjęcia założeń rosnącej we wpływy szkoły monetarystycznej, która odzwierciedlała ich spojrzenie na wagę polityki monetarnej dla rozwoju gospodarczego. Wśród niewielu głosów dysydenckich był prezes Banku Włoch, który - chociaż sam był zwolennikiem monetaryzmu - uważał, że gospodarka włoska nie powinna wchodzić do strefy euro opartej na takich zasadach; dla Włoch lepszym wyjściem jest akceptowanie niewielkiej inflacji i przeprowadzanie dewaluacji pozwalającej odzyskać konkurencyjność wobec silniejszych gospodarek z północy ${ }^{18}$. Z filozofią one fits all nie zgadzał się również prezes centralnego banku holenderskiego, który tuż przed ostatecznym podpisaniem traktatu w Maastricht twierdził, że na dobrą sprawę politycy dzierżący pióra w dłoni nie zdawali sobie sprawy z konsekwencji, jakie będzie miało przyjęcie wspólnej waluty w takim kształcie dla ich krajów ${ }^{19}$.

16 Ch. Wyplosz, European Monetary Union: The Dark Sides of a Major Success, „Economic Policy” 2006, vol. 21, nr 46, s. 247, [online] https://doi.org/10.1111/j.1468-0327.2006.00158.x.

17 One Market, One Money. An Evaluation of the Potential Benefits and Costs of Forming an Economic and Monetary Union, „European Economy” 1990, nr 44, [online] http://ec.europa.eu/economy_finance/ publications/pages/publication7454_en.pdf, 22 III 2018.

18 D. Marsch, The Europe's Deadlock. How the Euro Crisis Could be Solved - and Why It Won't Happen, Yale 2013, s. 89.

19 Tamże, s. 43. 
Po podpisaniu traktatu z Maastricht na zlecenie Komisji Europejskiej przygotowano kolejny raport: Stable Money - Sound Finances ${ }^{20}$. Najważniejsza konkluzja ekspertów brzmiała: A small budget will do (maty budzet wystarczy). W uzasadnieniu napisano: Gtównym przekazem raportu jest to, że maty budżet unii gospodarczo-walutowej o wysokości ok. 2\% PKB Wspólnoty jest wystarczajacy do utrzymania europejskiej unii ekonomicznej i monetarnej [...]. Stoi to w oczywisty sposób w sprzeczności z wielka częścia konwencjonalnej ekonomicznej mąrości, zawartej w raporcie MacDougalla, jak również $w$ relewantnej literaturze na temat unii ekonomicznej i monetarnej ${ }^{21}$. Jak widać, eksperci ekonomiczni byli w pełni świadomi, że to, co rekomendowali, stoi w sprzeczności z dotychczasowym dorobkiem nauk ekonomicznych.

Twórcy wspólnej waluty: Helmut Kohl, François Mitterrand i Jacques Delors, zdawali sobie sprawę z ułomności takiego rozwiązania i wielokrotnie przyznawali, że niezbędne będzie uzupełnienie go jakimś rodzajem unii fiskalnej, ale zakładali, że zostanie ona wprowadzona $\mathrm{w}$ dalszych etapach zacieśniania unii ${ }^{22}$. Kohl tuż przed podpisaniem traktatu z Maastricht stwierdził nawet, że unia walutowa bez równoległej unii politycznej będzie tylko zamkiem na piasku ${ }^{23}$. W podobnym tonie wypowiadał się kilka lat później przewodniczący Komisji Europejskiej Romano Prodi, który nie miał wątpliwości, że potrzebne będą dodatkowe instrumenty polityki ekonomicznej. W przeddzień wprowadzenia do obiegu banknotów i monet euro udzielił "The Financial Times” wywiadu, w którym stwierdził: Jestem pewny, że euro zobowiąże nas do wprowadzenia nowego zbioru instrumentów polityki ekonomicznej. W tym momencie jest to ze względów politycznych niemożliwe. Ale pewnego dnia nadejdzie kryzys i te nowe instrumenty zostanastworzone ${ }^{24}$.

Tak się jednak nie stało. Fundamentalnym założeniem unii gospodarczo-walutowej pozostała zasada, że kraje unii walutowej będą jedynie koordynowały swoje polityki ekonomiczne, bez zacieśniania współpracy, czyli budowania unii bankowej, finansowej i fiskalnej, które mogłyby zastąpić możliwość dewaluacji waluty i wykorzystywania banku centralnego jako „pożyczkodawcy ostatniej szansy” do amortyzowania szoków finansowych ${ }^{25}$. Żeby jednak zabezpieczyć się przed brakiem wspólnej polityki makroekonomicznej i wyeliminować niepożądane nierównowagi, wprowadzono pakt stabilności, którego nazwę na wniosek premiera Francji rozszerzono. Powołany w 1997 r. pakt stabilności i wzrostu miał sprzyjać utrzymaniu stabilności cen, co w dużej mierze w strefie euro się udawało, a także osiągnięciu silnego i trwałego wzrostu gospodarcze-

20 Stable Money - Sound Finances. Community Public Finance in the Perspective of EMU, „European Economy" 1993, nr 53, [online] http://ec.europa.eu/economy_finance/publications/pages/publication7524_en.pdf, 20 III 2018.

21 Tamże, s. 6.

22 D. Marsch, The Europe's Deadlock..., s. 153-155.

23 Tamże, s. 14.

24 Za: M. Matthijs, M. Blyth, The Future of the Euro, New York 2015, s. 249.

25 G. Sverker, What Makes a European Monetary Union without a Parallel Fiscal Union Politically Sustainable?, [w:] Political Aspects of the Economic and Monetary Union. The European Challenge, red. S. Dosenrode, Aldershot-Burlington 2002, s. 87-118. 
go, przyczyniającego się do zwiększania liczby miejsc pracy poza sektorem publicznym, co powiodło się znacznie gorzej.

\section{KRYZYS A IDEOLOGICZNY I PARADYGMATYCZNY GORSET}

To oparcie budowy europejskiej unii walutowo-gospodarczej na dorobku jednej szkoły ekonomicznej, skądinąd bardzo wtedy wpływowej, zostało post factum dostrzeżone i określone jako błąd nie tylko przez ekonomistów niechętnych monetaryzmowi, lecz także przez decydentów z instytucjonalnego rdzenia strefy euro. Vítor Constâncio, urzędujący wiceprezes Europejskiego Banku Centralnego (EBC), nazwał ten stan rzeczy ograniczeniami klimatu intelektualnego. Pisał on:

Częścia problemu jest to, że podejście przyjęte w odniesieniu do finansowej integracji $i$ aktywności bankowej odzwierciedlato dwie cechy dominującego wtedy myślenia w ekonomii. Po pierwsze, że sektor prywatny byt $w$ zasadzie stabilny $i$ samoregulujący [...]. $W$ takim świecie żadne bankructwa nie byty uznawane ani żadne bańki możliwe. Tylko sektor publiczny mógt kreować niestabilności - i dlatego wydawato się, że pakt stabilności i wzrostu będzie wystarczajacy dla zapewnienia stabilności. Po drugie, finanse nie byty uwzględniane jako czynnik majacy wptyw na fluktuacje w realnej gospodarce. Po szkole realnego cyklu ekonomicznego, teorii racjonalnych oczekiwań i paradygmacie międzyczasowych optymalizacji, pieniadze i finanse przestaty być traktowane jako istotne. Podczas gdy pieniadze znalazty z powrotem swoje miejsce w nowym konsensualnym modelu makroekonomicznym poprzez uznanie braku elastyczności ptac i cen, pozwalajac na krótkoterminowe efekty polityki monetarnej, finanse wcią̇ byty niewidzialne, co z hipoteza efektywnego rynku zapewnito prawdziwej gospodarce odpowiednia infrastrukturę. Banki i rynki kapitatowe nie byty traktowane jako endogeniczne źródto niestabilności, która mogtaby wywotać realne gospodarcze skutki. Byty nieobecne w makroekonomicznych modelach ${ }^{26}$.

Ten nieco przydługi cytat oddaje doskonale dwie bardzo istotne tezy, które chcę zaprezentować w niniejszej pracy. Pierwszą jest fakt, że przyjęta architektura strefy euro oparta była na określonej szkole intelektualnej dominującej w latach 80 . XX w. w światowej akademii, blisko związanej z ideologią neoliberalną. Drugą - to, że rozwiązania zawarte w traktacie z Maastricht, uzupełnione paktem stabilności i wzrostu i potwierdzone traktatem lizbońskim, okazały się niezdolne do powstrzymania kryzysu finansowego, który wybuchł w 2007 r. i przyczynił się do kryzysu strefy euro w 2010 r. Tym samym chcę pokazać, że dominująca narracja na temat tych wydarzeń jest w dużym stopniu błędna albo co najmniej mocno wypaczona. Jej centralnym argumentem jest to, że konstrukcja strefy euro była właściwa, a zarzewiem kryzysu stała się nieodpowiedzialna polityka kilku krajów peryferyjnych, które nie chciały się dostosować do ograniczeń wprowadzonych przez pakt stabilności i wzrostu, doprowadzając w ten sposób

26 V. Constancio, The European Crisis and the Role of the Financial System, mowa wygłoszona na konferencji „The crisis in the euro area”, Ateny, 23 V 2013, s. 3-4, [online] https://www.ecb.europa.eu/ press/key/date/2013/html/sp130523_1.en.html, 11 III 2018. 
do nadmiernego zadłużenia sektora publicznego i ostatecznie do braku wypłacalności. Ta niefrasobliwa polityka fiskalna spowodowała nadmierny wzrost płac i cen, który przyczynił się do utraty konkurencyjności i do konieczności rozpoczęcia procesu wewnętrznej dewaluacji. To mit, którego zadaniem jest legitymizacja dominującej pozycji w relacjach władzy.

Mit ten został wykreowany głównie na podstawie tych samych błędnych założeń makroekonomicznych, które przyczyniły się do destrukcyjnych konsekwencji kryzysu finansowego z 2007 r., a potem do kryzysu systemowego w strefie euro. Wielka recesja ponownie uruchomiła empiryczny i teoretyczny ferment pod nowy przełom paradygmatyczny i ideologiczny. Jeszcze kilka lat przed kryzysem wydawało się, że hegemonia rynkowych monetarystów jest niepodważalna. W 2004 r. wprowadzono do obiegu termin Great Moderation, który miał oznaczać, że rozwiniętym gospodarkom udało się na stałe wyjść z zaklętego kręgu cyklów gospodarczych powodujących gospodarczą destabilizację. Wierzono, że nie tylko znaleziono sposób na to, jak ograniczyć niekontrolowane wahania koniunkturalne, lecz także udało się skutecznie wyeliminować endogeniczne zagrożenia poważnymi recesjami ${ }^{27}$. Profesor Uniwersytetu w Chicago i laureat Nagrody Nobla Robert Lucas Jr. zasłynął w 2003 r. następującym oświadczeniem: Makroekonomia rozumiana w oryginalnym znaczeniu zwyciężyta: jej centralny problem polegajacy na powstrzymywaniu depresji zostat rozwiazany i w rzeczywistości rozwiąany na wiele dekad ${ }^{28}$. Ben Bernanke, w 2004 r. członek zarządu amerykańskiego banku centralnego, twierdził, że narzędzia do zarządzania nowoczesną ekonomią zostały dobrze zrozumiane i dlatego recesje stały się łagodne, a wiele wskazuje na to, że będzie się można ich pozbyć raz na zawsze - jego słowa przytacza Raghuram Rajan, ówcześnie główny ekonomista Międzynarodowego Funduszu Walutowego ${ }^{29}$. Alan Greenspan, szef amerykańskiego banku centralnego, nie tylko nie był w stanie wskazać żadnych przesłanek nadchodzącej katastrofy w 2007 r., on wręcz twierdzit - co jest znacznie bardziej istotne w kontekście intelektualnych słabości obowiązujących wtedy ekonomicznych modeli - że taka recesja nie miała prawa się zdarzyćc ${ }^{30}$. Z kolei tuż przed samym wybuchem wielkiej recesji główny ekonomista Międzynarodowego Funduszu Walutowego Olivier Blanchard oświadczył, że stan makro jest dobry, ponadto w dużym stopniu doszło do konwergencji stanowisk paradygmatycznych, uznających wyższość modelu neoklasycznego, na którym opierały się konsensus waszyngtoński oraz europejska unia walutowa ${ }^{31}$.

27 B. Bernanke, The Great Moderation, mowa wygłoszona na spotkaniu Eastern Economics Association, Waszyngton, 20 II 2004, [online] https://www.federalreserve.gov/boarddocs/speeches/2004/20040220/, 5 III 2018.

28 R. Lucas Jr., Macroeconomic Priorities, „American Economic Review” 2003, vol. 93, nr 1, [online] https://doi/10.1257/000282803321455133.

29 Za: R.G. Rajan, Fault Lines. How Hidden Fractures still Threaten The World Economy, Princeton 2010, s. 118 .

30 Tamże, s. 9-15.

31 O. Blanchard, The State of Macro, „Annual Review of Economics” 2008, vol. 1, nr 1, s. 2, [online] https://doi.org/10.3386/w14259. 
Miałkość tych obserwacji została dostrzeżona już w 2009 r. Wielokrotnie cytowane od tamtej pory słowa Willema Buitera, brytyjskiego ekonomisty i byłego członka Rady Banku Anglii, podały w wątpliwość cały dorobek ekonomii głównego nurtu ostatnich czterech dekad. Buiter stwierdził:

Większość teoretycznych innowacji w makroekonomii gtównego nurtu od lat 70. [...] okazata sie $w$ najlepszym razie odnoszacym się do siebie i nakierowanym do wewnatrz zawracaniem gtowy. Badania na ogót bardziej kierowaty się wewnętrzna logika, zasiedziatym kapitatem intelektualnym i estetycznymi zagadkami uznanych programów badawczych niż potężnym pragnieniem zrozumienia, jak ekonomia naprawdę dziata - a co dopiero jak dziata podczas napięć i niestabilności. Tak więc kiedy kryzys uderzyt, ekonomia jako dyscyplina byta nieprzygotowana ${ }^{32}$.

Ta dosyć radykalna diagnoza znalazła potwierdzenie w pracy wybitnych ekonomistów teoretyków.

W 2016 r. z wielowymiarową i głęboką krytyką swojej dyscypliny wystąpił jeden z prominentnych przedstawicieli szkoły chicagowskiej, Paul Romer, oznajmiając, że makroekonomia głównego nurtu znalazła się $\mathrm{w}$ fazie intelektualnego regresu i to już od ponad trzech dekad ${ }^{33}$. Z kolei w opublikowanej w styczniu 2018 r. pracy pod znamiennym tytułem Rebuilding Macroeconomic Theory 16 autorów, w tym 2 noblistów w zakresie ekonomii, zgodziło się z tezą, że obowiązująca w ostatnich dekadach makroekonomiczna doksa jest nie do obrony ${ }^{34}$. Twierdzą oni ponadto, że do porażki neoklasycznej makroekonomii przyczyniła się hipoteza efektywnych rynków i teoria racjonalnych oczekiwań ${ }^{35}$ - czyli dokładnie te składniki makroekonomicznego modelu, które zostały zidentyfikowane przez wiceprezesa EBC jako źródło kryzysu strefy euro. Kwestie związane z ograniczeniami intelektualnymi i ideologicznymi preferencjami czasów, w których wykuwano konstrukcję euro, zakończę słowami naczelnego ekonomisty „The Financial Times”. Z rozbrajającą szczerością przyznał on, że analiza teorii makroekonomicznej wskazuje na istotna ignorancję znajomości dziatania ekonomii ${ }^{36}$. Przy czym ta ignorancja nie pojawiła się w wyniku kryzysu, który przyniósł ze sobą zjawiska emergentne; istniała już przed kryzysem i przyczyniła się do jego nadejścia.

32 W. Buiter, The Unfortunate Uselessness of Most "State of the Art" Academic Monetary Economics, VoxEU, Research-based policy analysis and commentary from leading economists, 6 III 2009, [online] https://ssrn.com/abstract=2492949, 12 XIII 2013.

33 P. Romer, The Trouble with Macroeconomics, Commons Memorial Lecture of the Omicron Delta Epsilon Society, New York University, 5 I 2016, [online] https://paulromer.net/wp-content/uploads/2016/09/WP-Trouble.pdf, 11 XI 2016.

34 D. Vines, S. Wills, Rebuilding Macroeconomic Theory, „Oxford Review of Economic Policy” 2018, vol. 34, nr 1-2, [online] https://doi.org/10.1093/oxrep/grx062.

35 Tamże, s. 20.

36 M. Wolf, Economics Failed Us before the Global Crisis, „The Financial Times” 2018, 20 III, [online] https://www.ft.com/content/28e2f9ac-2b66-11e8-9b4b-bc4b9f08f381, 21 III 2018. 


\section{EKONOMICZNE DOMINO W STREFIE EURO}

Teoria racjonalnych oczekiwań i hipoteza efektywnych rynków legły u podstaw instytucjonalnej konstrukcji strefy euro. Pierwsza została ucieleśniona w modelu EBC, który odzwierciedlał filozofię ordoliberalnego Bundesbanku. Opierała się ona na przekonaniu, że najważniejsza dla zabezpieczenia wzrostu gospodarczego jest stabilność monetarna (to zresztą zasada zapisana w niemieckiej konstytucji), stąd wyjęcie polityki monetarnej spod politycznych wpływów i podporządkowanie jej nadrzędnemu celowi, jakim była niska inflacja, nawet jeśli miałaby zostać osiągnięta kosztem wzrostu gospodarczego i wysokiego bezrobocia. Hipoteza efektywnych rynków leżała u podstaw filozofii regulacji gospodarczej w strefie euro. Ograniczenie jej wyłącznie do finansów publicznych stało za wprowadzeniem paktu stabilności i wzrostu. Europejscy decydenci uznali, że źródłem nierównowagi mogły być wyłącznie nieodpowiedzialne decyzje polityczne, przekładające się na deficyty budżetowe i pogłębiający się dług publiczny poszczególnych państw członkowskich. Stąd przyjęte zupełnie arbitralnie wartości krytyczne: 3\% dla deficytu budżetowego i 60\% dla długu publicznego. Próżno szukać dla nich racjonalnych uzasadnień czy empirycznych podstaw. Trudno oprzeć się wrażeniu, że ich wartość wynika ze słynnej tezy Reinhart i Rogoffa, jakoby dług publiczny w wysokości $90 \%$ miał negatywny wpływ na wzrost gospodarczy ${ }^{37}$. Jak wiadomo, dość szybko okazało się, że po pierwsze liczba ta wynika z błędu popełnionego podczas obliczeń $^{38}$, po drugie - samo założenie o powiązaniu wysokiego długu z mniejszym wzrostem nie ma wystarczająco solidnych fundamentów ${ }^{39}$. Sprawa ta nie miała wyłącznie akademickiego charakteru. Wiceprezydent Komisji Europejskiej ds. Ekonomii i Spraw Finansowych powoływał się w 2011 r. na ustalenia Reinhart i Rogoffa w celu wymuszenia na państwach członkowskich większej dyscypliny fiskalnej ${ }^{40}$, czyli zmniejszenia wydatków i podniesienia podatków, co przełożyło się na wzmocnienie prorecesyjnych tendencji cyklu gospodarczego, a więc na pogłębienie kryzysu. Sfera prywatna miała się regulować samoistnie, wolne rynki miały wykazać się wyższością w alokacji zasobów i, zgodnie z tą wiarą, zawsze zmierzać do równowagi i unikać nadmiernego ryzyka, a przynajmniej ryzyka o charakterze systemowym.

Analiza kondycji finansów publicznych sprzed kryzysu pokazuje jednak, że te założenia były błędne. Długi publiczne w niektórych krajach nie miały nic wspólnego z wybuchem kryzysu, wręcz przeciwnie - niektóre kraje ze znakomitymi wskaźnikami odczuły go najboleśniej. W Hiszpanii dług publiczny zmniejszył się w latach 1999-2007

37 C.M. Reinhart, K.S. Rogoff, Growth in a Time of Death, „NBER Working Paper” 2010, nr 15639, [online] http://www.nber.org/papers/w15639, 8 II 2014.

38 T. Harndon, M. Ash, R. Pollin, Does Public Debt Consistently Stifle Economic Growth? A Critique of Reinhart and Rogoff, „PERI Working Paper” 2013, nr 332.

39 The Good, the Bad, and the Ugly: 100 Years Dealing with Public Debt Overhang, „IMF World Economic Outlook", X 2012.

40 O. Rehn, Debt, Governance and Growth: A Euro Area Perspective, 2011, [online] http://europa.eu/ rapid/press-release_SPEECH-11-407_en.htm, 5 III 2018. 
z 62,4\% PKB do 36,3\% PKB, w Irlandii zaś spadł z 47\% PKB do 25\% PKB ${ }^{41}$. Dla porównania w tym samym czasie zadłużenie sektora publicznego Belgii wynosiło $100 \%$ PKB. Wysoki dług miały Włochy, ale z tendencją spadkową; jedynie w Grecji wzrósł on nieco w owym czasie. Widać więc, że - poza Grecją - kraje peryferyjne prowadzity raczej zdyscyplinowaną politykę i wypełniały wymagania związane z porzuceniem własnej waluty, a wraz z nią suwerenności monetarnej. Mówiąc inaczej: Hiszpania, Irlandia i Włochy dotrzymywały umowy wynikającej z konstrukcji strefy euro. Jako kraje ją naruszające można natomiast wskazać Niemcy i Francję, które nie chciały się poddać rygorom wynikającym z paktu stabilności i wzrostu w latach 2003-2004.

Co zatem doprowadziło te kraje na skraj bankructwa? Odpowiedź brzmi: sektor prywatny. W pierwszych siedmiu latach funkcjonowania wspólnej waluty jego zadłużenie wzrosło w Grecji o 217\%, w Irlandii o 101\%, w Hiszpanii o 75,2\%, a Portugalii o 49\%. Nikt nie zorientował się, że tak gwałtowny wzrost zadłużenia sektora prywatnego może być niebezpieczny, ponieważ wraz z przyjęciem wspólnej waluty doszło do olbrzymiej ekspansji kredytowej instytucji finansowych z krajów centrum do krajów peryferyjnych. W dużej mierze przyczyniło się do tego spowolnienie konsumpcji i inwestycji w krajach centrum, szczególnie w Niemczech. Rząd niemiecki pod przywództwem Gerharda Schrödera forsował zbiór reform pod nazwą Agenda 2010, które miały znacznie odchudzić niemieckie państwo dobrobytu. W pakiecie znalazły się tzw. reformy Hertza, ograniczające prawa do świadczeń wynikających ze statusu bezrobotnego, zderegulowano także kodeks pracy, otwierając drogę dla tzw. niskopłatnych mini i midi miejsc pracy. W sumie w bardzo poważny sposób ograniczono popyt i konsumpcję wewnętrzną w Niemczech. Efektem tej jednostronnej polityki gospodarczej było m.in. uwolnienie olbrzymiej ilości kapitału, który, żeby nie leżeć bezczynnie, natychmiast ruszył do krajów peryferyjnych strefy euro ${ }^{42}$. Widać to było głównie na przykładzie przerostów inwestycyjnych w sektorze budowlanym Hiszpanii, Grecji i Irlandii. Wyolbrzymione apetyty konsumpcyjne na peryferiach sprzyjały również gospodarkom krajów centrum. Zadłużający się obywatele krajów Południa mogli przez swoje wydatki wspierać wzrost gospodarczy i eksport krajów Północy. Największym tego beneficjentem były Niemcy, których eksport w strefie euro rósł bardzo dynamicznie ${ }^{43}$. W $2007 \mathrm{r}$. niemiecka nadwyżka w handlu z krajami strefy euro wynosiła $100 \mathrm{mld}$ euro ${ }^{44}$.

W takiej sytuacji naturalną reakcją byłoby podniesie stóp procentowych w krajach o dużej konsumpcji, jednak EBC - ze względu na to, że wyznaczał stopy dla całej strefy euro - zdecydował się na utrzymywanie ich na niskim poziomie, by wspierać gospodarki krajów centrum. Przy braku instrumentów umożliwiających schładzanie gorączki kredytowej jedynym zabezpieczeniem przed niefrasobliwym udzielaniem pożyczek

41 V. Constancio, The European Crisis..., s. 1.

42 F.-J. Meiers, Germany's Role in the Euro Crisis. Berlin's Quest for a More Perfect Monetary Union, New York 2015, s. 20-21.

43 S. Kawalec, E. Pytlarczyk, Paradoks euro. Jak wyjść z putapki wspólnej waluty?, Warszawa 2016, s. 182.

44 W. Jacoby, Europe's New German Problem: The Timing of Politics and the Politics of Timing, [w:] The Future of the Euro..., s. 207. 
były prywatne banki i instytucje finansowe. Zgodnie z teorią, to one najlepiej wiedziały, na co udzielić kredytów, czy te pożyczki mają szansę na spłatę, jakie jest ryzyko bankructwa i kto poniesie jego koszty. Prywatni aktorzy rynku finansowego mieli zachowywać się tak, jak zakładano w hipotezie efektywnych rynków, tzn. działać w najbardziej optymalny i racjonalny sposób, tak żeby ograniczyć ryzyko do minimum. Zakładano, że prywatny kapitał będzie przepływał przeciwcyklicznie i stabilizował deficyty i nadwyżki wykreowane przez państwa ${ }^{45}$. Tak się jednak nie stało: prywatny kapitał nie wykazał się wyższą ostrożnością, tak jakby inwestorzy założyli, że kraje strefy euro mają gwarancję ochrony przed bankructwem.

Wartość kredytów udzielonych przez instytucje krajów centrum krajom peryferyjnym wzrosła w ciągu siedmiu lat ponad pięciokrotnie. Szacuje się, że same banki niemieckie udzieliły tylko w Hiszpanii kredytów na ponad 300 mld euro do 2005 r. ${ }^{46}$ Ten zwiększony napływ kapitału do krajów Południa miał być uzasadniony wyższym wzrostem gospodarczym osiąganym dzięki większej produktywności uzyskanej z inwestycji pochodzących z kapitału z Północy. Tłumaczenia te, jak się okazało, były zupełnie oderwane od realiów ${ }^{47}$. Kredyty niemieckie w Hiszpanii w 2008 r. wynosiły bowiem już 700 mld euro - dla tak gigantycznego skoku w napływie kapitału nie można znaleźć żadnych racjonalnych przesłanek ekonomicznych ${ }^{48}$. Hipoteza o racjonalnych rynkach w tym wypadku pozostała jedynie hipotezą.

Wybuch kryzysu i początek recesji zagroził systemowym załamaniem nie tylko krajom peryferii, lecz także sektorowi finansowemu krajów centrum. Bankructwo groziło gospodarkom krajów peryferyjnych i systemowi finansowemu Niemiec i Francji, krajów, które udzieliły najwięcej kredytów. Problem stał się zbyt duży, żeby pozostawić go wyłącznie rynkom.

\section{PUŁAPKA TRAKTATU LIZBOŃSKIEGO}

Dotychczas analizie poddano te elementy architektury strefy euro, które odegrały ważną rolę w powstaniu kryzysu. Kolejnym krokiem będzie przyjrzenie się, dlaczego kryzys nie zakończył się tak szybko, jak w Wielkiej Brytanii i w USA, a także co spowodowało, że jego przebieg był znacznie ostrzejszy i dlaczego przestał być tylko kryzysem finansowym w strefie euro, a stał się kryzysem systemowym strefy euro, egzystencjalnym zagrożeniem dla obszaru wspólnej waluty i całej Unii Europejskiej.

W niniejszym artykule stawiam tezę, że decydującym czynnikiem przekształcającym kryzys finansowy w kryzys systemowy strefy euro były traktatowe rozwiązania leżące

45 E. Clancy, The Future of the Eurozone, European United Left/Nordic Green Left (GUE/NGL), 2017, s. 27.

46 A. Newman, The Reluctant Leader: Germany's Euro Experience and the Long Shadow of Reunification, [w:] The Future of the Euro..., s. 123.

47 J. Hopkin, The Troubled Southern Periphery: The Euro Experience in Italy and Spain, [w:] The Future of the Euro..., s. 166-167.

48 C. Lapavitsas [i in.], Crisis in the Eurozone, New York 2012, s. 100. 
u podstaw wspólnej waluty oraz niechęć decydentów do przyjęcia odważnych rozwiązań, co przejawiało się odkładaniem decyzji do momentu, kiedy nie można było już przed nimi uciec. Wydaje się, że panuje zgoda co do tego, iż instytucje Unii Europejskiej nie zdały egzaminu z kryzysu. Działały zbyt wolno i kładły zbyt duży nacisk na dyscyplinę, a zbyt mały na efektywne rozwiązywanie problemów. Kiedy były konieczne szybkie decyzje, zabrakło sprawczości i uznaniowości lub pojawiły się one zdecydowanie zbyt późno ${ }^{49}$. Problem ten był wynikiem strukturalnych cech w dużej mierze postpolitycznej i postdemokratycznej Unii Gospodarczej i Walutowej, rządzonej przez zasady i normy.

Jednym z najsłabszych punktów konstrukcji wspólnej waluty była likwidacja funkcji banku centralnego nazywanej „pożyczkodawcą ostatniej szansy”. To dzięki niej każdy kraj posiadający własny bank centralny i własną walutę, w której jest zadłużony, jest chroniony przed bankructwem. W kryzysie, kiedy rosną koszty obsługi długu publicznego i pojawia się brak płynności finansowej, rząd może po prostu poprosić swój bank centralny o udzielenie dalszego kredytu. W taki sposób na kryzys zareagowały m.in. banki centralne w Wielkiej Brytanii, Stanach Zjednoczonych i Japonii.

W strefie euro sytuacja była inna. Państwa członkowskie przekazały kompetencje swoich byłych banków centralnych nowej instytucji, czyli EBC, i to od niej, a także od zapisów traktatowych, na podstawie których działała, zależał w dużej mierze przebieg kryzysu. Jeśli chodzi o zapisy traktatowe, sytuacja była od początku bardzo trudna. Już w traktacie z Maastricht sformułowano zakaz pomocy poszczególnym rządom w przypadku kryzysu. Traktat z Lizbony zapisy te potwierdzał i wzmacniał. Zgodnie z art. 123, 124 i 125 ani EBC, ani inne państwa członkowskie Unii Europejskiej nie mogły interweniować w celu ratowania innych państw w kryzysie. Warto zauważyć, że do wybuchu kryzysu na rynkach finansowych panowało jednak przekonanie, że w sytuacji realnego zagrożenia państwa strefy euro zmobilizują się w celu obrony wspólnego dobra publicznego, jakim jest bezpieczna i godna zaufania waluta. Dlatego choć nie zawsze wszystkie kraje mogły się pochwalić podobną kondycją swoich gospodarek, ich dług wyceniany był przez te rynki niemal identycznie. Rząd grecki czy portugalski płacił niemal takie same odsetki od obligacji, jak rząd niemiecki czy holenderski. Było to zresztą zgodne z logiką EBC, który, ustanawiając jedną stopę procentową dla wszystkich krajów, przyznawał, że długi krajów strefy euro są zabezpieczone na równi. Było to jednak sprzeczne z traktatem lizbońskim i kiedy doszło do kryzysu, okazało się, że ta domniemana solidarność jest fikcją.

Najpierw ECB dał do zrozumienia, że nie pójdzie śladem banków centralnych w UK, USA i Japonii, które już w 2009 r. uruchomiły pierwsze transze kapitału w ramach operacji „luzowania ilościowego” (quantitative easing). Z kolei w 2010 r. rząd Niemiec oświadczył, że ani on, ani EBC nie przyjmą roli „pożyczkodawcy ostatniej szansy", bo zabraniają tego traktaty ${ }^{50}$. To otworzyło rynkom finansowym drogę do

49 V.A. Schmidt, The Forgotten Problem of Democratic Legitimacy: "Governing by the Rules" and "Ruling by the Numbers", [w:] The Future of the Euro..., s. 92-94.

50 M. Matthijs, M. Blyth, Introduction: The Future of the Euro and the Politics of Embedded Currency Areas, [w:] The Future of the Euro..., s. 3. 
rozpoczęcia spekulacji, które doprowadziły do tego, że obsługa długu publicznego krajów peryferyjnych zaczęła kosztować niemal z dnia na dzień kilkakrotnie więcej. Pozbawione własnych suwerennych banków centralnych, które powinny pospieszyć z nisko oprocentowanymi kredytami dla swoich rządów, kraje musiały zdecydować się na gwałtowne cięcia wydatków i podwyżki podatków. Rezultatem było coraz większe spowolnienie gospodarcze i coraz niższe wpływy z podatków; skarbce państw pustoszały w zawrotnym tempie. W Hiszpanii rok kryzysu pozbawił budżet państwa 70 mld euro. Paul de Grauwe stwierdził, że właśnie na tym polega centralny problem takich unii walutowych, jak euro: rządy narodowe padają ofiarą paniki na rynkach finansowych, a te, pozbawione tradycyjnych narzędzi w postaci automatycznych stabilizatorów, stają się łatwym łupem finansowych spekulantów ${ }^{51}$.

Kraje peryferii znalazły się więc w sytuacji, w której warunki zaczęli dyktować politycy krajów Północy. Otrzymały obietnicę pomocy, ale za cenę przejęcia długów sektora prywatnego. Tym sposobem kryzys, po części wywołany niefrasobliwością pożyczkodawców sektora prywatnego, został przerzucony niemal w całości na społeczeństwa. Prywatne zyski przerośniętego sektora finansowego zostały zastąpione uspołecznionymi stratami.

\section{POLITYCZNA OFENSYWA}

Państwa członkowskie strefy euro zmobilizowały dodatkowy kapitał ratunkowy w zamian za zgodę na wdrożenie polityki wyrzeczeń. W 2010 r. powołano nową instytucję: Europejski Instrument Stabilności Finansowej. Ponieważ to, czym miała się zajmować, jest sprzeczne z traktatem z Lizbony, powołano ją w formule międzyrządowej jako spółkę z ograniczoną odpowiedzialnością zarejestrowaną w Luksemburgu. Grecja otrzymała $110 \mathrm{mld}$ euro pożyczki, Irlandia $85 \mathrm{mld}$, Portugalia 78 mld. Uruchomiono również Securities Markets Programme, czyli program olbrzymich zakupów obligacji rządowych zadłużonych krajów na rynkach wtórnych przez EBC. Interwencje te dotyczyły przede wszystkim sekurytyzacji długu włoskiego i hiszpańskiego. W praktyce oznaczało to złamanie konsensusu politycznego, na podstawie którego działał EBC, i zakwestionowanie zapisów traktatu z Lizbony. $\mathrm{Na}$ znak protestu do dymisji podał się członek zarządu EBC reprezentujący Niemcy, Jürgen Stark.

W 2011 r. doprowadzono do formalnej zmiany art. 136(3) traktatu lizbońskiego. Skorzystano z tzw. procedury kładki (passerelle), czyli uproszczonej procedury zmiany traktatów, dzięki której ograniczono wątpliwości prawne - przede wszystkim w Niemczech, ale też $w$ innych krajach strefy euro. Znowelizowany artykuł został uzupelniony o słowa dające krajom strefy euro możliwość powołania do życia mechanizmu

51 P. de Grauwe, The Limits of the Market. The Pendulum between Government and Market, przel. A. Asbury, Oxford 2017, s. 118-120; P. de Grauwe, Y. Ji, Panick-Driven Austerity in the Eurozone and Its Implications, VOX CEPR's Policy Portal, 21 II 2013, [online] https://voxeu.org/article/panic-driven-austerity-eurozone-and-its-implications, 3 III 2018. 
stabilizacyjnego, który mógłby zostać użyty, kiedy konieczne byłoby ratowanie stabilności strefy euro jako całości. Udzielenie wsparcia finansowego miałoby się odbywać tylko w ściśle określonych warunkach ${ }^{52}$. Ta nowelizacja stoi w zgodzie z rozstrzygnięciem Europejskiego Trybunału Sprawiedliwości (ETS), który na prośbę Sądu Najwyższego Irlandii badał, czy tego typu interwencje nie stoją w sprzeczności z traktatem lizbońskim. Trybunał w Luksemburgu uznał, że nie, ale pod warunkiem, że celem działania jest ratowanie całej strefy euro, a nie pojedynczych państw. ETS „odkryl” więc $\mathrm{w}$ interpretacji nowy, nadrzędny cel unii gospodarczo-walutowej, którym jest obrona stabilności całej strefy euro ${ }^{53}$. Tym sposobem otwarto drogę do powołania $\mathrm{w}$ ramach prawnych Unii Europejskiej Europejskiego Mechanizmu Stabilności, mającego przyjąć rolę „pożyczkodawcy ostatniej szansy”.

Rewolucyjną zmianą dla EBC okazała się również zmiana w jego przywództwie. Po tym, jak niezwykle zachowawczy prezes Jean-Claude Trichet przekazal fotel prezesa Banku Mario Draghiemu, działania EBC stały się znacznie bardziej ofensywne. Draghi uznał, że w walce z kryzysem konieczne są niekonwencjonalne metody działania. Najpierw wygłosił w Londynie zdanie, które przejdzie do historii: $W$ ramach swojego mandatu ECB zrobi wszystko konieczne, żeby uratować euro. I wierzcie mi - to będą kroki wystarczające ${ }^{54}$. Następnie przystąpił do uruchamiania Outright Monetary Transaction - nowego mechanizmu skupującego długi rządowe. To wystarczyło, żeby uspokoić rynki finansowe i zatrzymać spekulacje, co z kolei przełożyło się na szybki spadek cen długów krajów Południa. W 2014 r. Draghi uruchomił program „luzowania ilościowego", a więc mechanizm, który skutecznie zatrzymał lawinę bankructw w Wielkiej Brytanii i w Stanach Zjednoczonych.

\section{OD KOORDYNACJI DO WSPÓLNEJ POLITYKI GOSPODARCZEJ?}

W 2015 r. PKB strefy euro prawie powrócił do rozmiaru sprzed kryzysu, a w 2017 r. wzrost gospodarczy wyniósł 2,5\% i był największy od 2007 r. Po 10 latach największego kryzysu w historii Wspólnot Europejskich wiele wskazuje na to, że - jak chciał Hipokrates - najgorsze minęło i pacjent będzie żył. Nie znaczy to jednak, że ustąpiły przyczyny choroby. Wciąż nie osiągnięto zgody co do tego, jak przebudować strefę euro w taki sposób, żeby zabezpieczyć ją przed podobnymi zapaściami i sprawić, aby sprzyjała ona konwergencji gospodarek w jej obrębie, zachowując gospodarczą dynamikę. Zasada konwergencji przyświeca integracji europejskiej od samego początku

52 Directorate General for Internal Policies, Policy Department C: Citizen's Rights and Constitutional Affairs, Article 136 TFEU, ESM, Fiscal Stability Treaty Ratification requirements and present situation in the Member States, 2013, [online] http://www.europarl.europa.eu/meetdocs/2009 2014/documents/afco/dv/2013-06-12_pe462455-v16_/2013-06-12_pe462455-v16_en.pdf, s. 4, 17 III 2018.

53 A. Hinarejos, The Euro Area Crisis in Constitutional Perspective, Oxford 2015, s. 121-144.

54 Szef EBC Mario Draghi pod presja oczekiwań, „Forbes” 2012, 3 IX, [online] https://www.forbes.pl/ wiadomosci/szef-ebc-mario-draghi-pod-presja-oczekiwan/00d6qgp, 3 III 2018. 
i potwierdzona została ostatnio przez przywódców państw członkowskich i Unii Europejskiej w Deklaracji rzymskiej 25 marca 2017 r. $^{55}$

Dziś wiadomo, że aby przetrwać, europejska unia walutowa musiała odrzucić część dogmatów, na których została ufundowana. Europejski Bank Centralny nie mógł trzymać się ściśle przewidzianej dla niego w traktatach roli, bo doprowadziłoby to do kompletnego rozpadu strefy euro. Co więcej, zdaniem wielu badaczy EBC zdecydowanie wykroczył w trakcie kryzysu poza swoje traktatowe kompetencje. Stał się członkiem Troiki, która decyduje o skali i treści polityki zaciskania pasa, oddano mu nadzór nad bankami i właściwie decyduje o ich losie, stał się europejskim głosem w uzgadnianiu regulacji finansów na świecie, pomaga finansowo rządom oraz prywatnym firmom, czyli tak naprawdę posiada wpływ na ich ewentualne sukcesy i porażki. To rozbudowanie kompetencji EBC, który miał być odizolowany od polityki, nie zostało uzupełnione żadnym mechanizmem legitymizującym jego decyzje. EBC jest wciąż pozbawiony jakiegokolwiek nadzoru demokratycznego i wyjęty spod europejskich standardów transparentności ${ }^{56}$. Zdaniem niektórych konstytucjonalistów ta ewolucja kompetencji EBC oznacza jakościową zmianę, polegającą na przejściu z instytucji opartej w swoich działaniach na normach i zasadach pochodzących z zewnątrz w instytucję podejmującą uznaniowe decyzje, a więc prowadzącą politykę. Alicia Hinarejos z Uniwersytetu w Cambridge twierdzi wręcz, że wiele z tzw. niekonwencjonalnych działań EBC wyszło poza traktatowe kompetencje ograniczone do polityki monetarnej i stało się elementem polityki ekonomicznej par excellence ${ }^{57}$. Strefa euro zmaga się więc z nowym poważnym deficytem legitymizacyjnym i demokratycznym, ponieważ wszędzie tam, gdzie udziela się mandatu do podejmowania uznaniowych decyzji, niezbędna jest demokracja, legitymizacja i transparentność.

Wprowadzone ad hoc instrumenty finansowego wsparcia dla sektora prywatnego i publicznego w krajach peryferyjnych, czyli: Securities Market Programme, Long Term Refinancing Operations, Outright Monetary Transactions, Asset-Backed Securities Purchase Programme, Public Sector Purchase Programme, Corporate Sector Purchase Programme okazały się co prawda skuteczne w działaniu, ale sprzeczne z duchem traktatu z Maastricht i traktatu z Lizbony, które zabraniały udzielania pomocy zagrożonym rządom. Żeby całkiem nie pogrzebać litery i ducha traktatu, stworzono więc zręby wspólnej polityki gospodarczej poza traktatami. W 2010 r. utworzono Europejski Instrument Stabilności Finansowej i Europejski Mechanizm Stabilizacji Finansowej, w 2011 r. wprowadzono praktykę semestru europejskiego, w 2012 r. powstał Europejski Mechanizm Stabilności, a w 2013 r. traktat o stabilności, koordynacji i zarządzaniu w Unii Gospodarczej i Walutowej (pakt fiskalny).

Semestr europejski oraz pakt fiskalny to narzędzia zwiększonej koordynacji ekonomicznej przy jednoczesnym zwiększeniu dyscypliny w egzekwowaniu zasad

55 The Rome Declaration. Declaration of the Leaders of 27 Member States and of the European Council, the European Parliament and the European Commission, [online] http://www.consilium.europa.eu/en/ press/press-releases/2017/03/25/rome-declaration/pdf, 10 II 2018.

56 S. Jourdan, Unprecedented Coalition of MEPs against The ECB's Lack of Transparency, 2 VI 2017, [online] http://www.qe4people.eu/mario_draghi_dodges_transparency_eu_parliament, 15 III 2018.

57 A. Hinarejos, The Euro Area Crisis..., s. 129. 
wynikających z paktu stabilności i rozwoju. W praktyce oznacza to, że każdy budżet państwa członkowskiego musi przed przyjęciem przez narodowy parlament zostać zaakceptowany przez Komisję Europejską. Łamanie dyscypliny finansowej może pociągnąć za sobą wysokie finansowe sankcje nakładane na wniosek Komisji. Mechanizm ten ma jednak charakter asymetryczny. Kraje z wysokimi deficytami mogą być dyscyplinowane przez nakładanie kary finansowej, co jeszcze bardziej zmniejsza zdolność ich gospodarek do ekspansji, natomiast nie istnieją żadne narzędzia mogące wymusić zmianę w krajach o dużych nadwyżkach budżetowych ${ }^{58}$. Brak równowagi w kompetencjach Komisji i jej zdolności do podejmowania działań dyscyplinujących w przypadku zbyt dużych asymetrii rodzi pytanie nie tylko o kwestie legitymizacji i demokratycznego mandatu, lecz także o skuteczność wykluwającej się wspólnej polityki ekonomicznej.

Ruszyła również budowa unii finansowej, której głównym zadaniem będzie redukcja i regulacja ryzyka i niepewności finansowej. Efektem tych działań jest powstająca unia bankowa. Jej celem ma być objęcie nadzorem i procedurami naprawczymi wszystkich najważniejszych banków w strefie euro. Nadzór taki miałby uodpornić instytucje finansowe z różnych krajów na ataki paniki i nieprzewidzialne, gwałtowne przepływy kapitału, które okazały się zabójcze dla gospodarki całej strefy euro. Silna unia bankowa powinna gwarantować stabilność i wypłacalność wszystkich banków działających w jednym systemie finansowym. Na razie nie wiadomo jednak, jaki kształt przybierze, ponieważ rząd niemiecki obawia się włączenia w nią gwarancji depozytów.

Jak anatema traktowana jest również wszelka próba mutualizacji zadłużenia w strefie euro. Głównym politycznym przeciwnikiem tego rozwiązania jest Angela Merkel, która pod tym, jak oznajmiła w Bundestagu, że nie dojdzie do tego, dopóki żyje, ma związane ręce w tej kwestii ${ }^{59}$.

Pojawiła się natomiast na horyzoncie możliwość powstania mechanizmu redystrybucji i ekonomicznego dostosowywania. Znalazła się ona w propozycji reformy strefy euro zarysowanej przez Emmanuela Macrona w mowie na paryskiej Sorbonie. Według niego unia gospodarcza i walutowa na obraz innych federacji posiada własny budżet i demokratyczną reprezentację, dzięki czemu może powstać szansa na aktywną i interwencyjną politykę gospodarczą oraz jakieś formy redystrybucji w strefie euro. Jest to propozycja, która powraca do wizji integracji proponowanych przed dominacją paradygmatu monetarystycznego, w których mówiło się o wspólnym budżecie, ekonomicznej polityce i demokratycznej legitymizacji. Nawiązuje do propozycji zawartych w planach Wernera i MacDougalla. Tak więc być może rację ma Paul de Grauwe, dyrektor Instytutu Europejskiego London School of Economics, który twierdzi, że po tym, jak w latach 80. XX w. wahadło ideologiczne i polityczne przesunęło się w stronę rynku, teraz będzie zmierzać w stronę interwencjonizmu ${ }^{60}$. Oczywiście nie wiadomo, czy Francja zdoła

58 European Commission, Communication from The Commission to The European Parliament, The Council, The European Economic and Social Committee and the Committee of the Regions towards a Positive Fiscal Stance for the Euro Area, 2016, s. 3, [online] https://ec.europa.eu/info/sites/info/ files/2017-european-semester-communication-fiscal-stance_en_1.pdf, 15 III 2018.

F.-J. Meiers, Germany's Role in the Euro Crisis..., s. 37.

60

P. de Grauwe, The Limits of the Market... 
przeforsować swój plan i nawet jeśli tak, to na ile zmiana działania strefy euro będzie miała charakter jakościowy. Wolfgang Streeck twierdzi, że w drugiej dekadzie XXI w. transfery w obrębie europejskiej unii walutowej powinny wynosić co najmniej $4 \%$ jej PKB. Jak sam jednak przyznaje, takiej woli politycznej w Niemczech obecnie nie ma ${ }^{61}$.

\section{ZAKOŃCZENIE}

Bez systemowej zmiany strefy euro pozostanie jedynie program polegający na tzw. reformach strukturalnych, czyli deregulacji rynku pracy i dalszym obniżeniu płac. Głównym założeniem tych rozwiązań jest przekonanie, że wszystkie kraje strefy euro mogą się stać tak samo konkurencyjne, jak gospodarka niemiecka ${ }^{62}$. Heikki Patomäki twierdzi, że to typowy błąd kompozycji. To, co jest w danych warunkach dobre dla jednych, może nie być dobre dla wszystkich. Jeśli wszystkie gospodarki przekształcą się w gospodarki nastawione na eksport, kto będzie importował? Jeśli wszyscy będą mieli nadwyżkę budżetową, kto będzie miał deficyt? Jeśli wszyscy będą oszczędzać, kto będzie wydawał? ${ }^{63}$

Pojawia się również pytanie: czy wszystkie kraje mogą i chcą dostosować swoje społeczeństwa i kultury do modelu niemieckiego? Istnieje wiele przesłanek, by w to wątpić $^{\prime 4}$. Jak pokazuje doświadczenie krajów, które wybrały zdecydowaną deregulację rynku pracy, jej efektem jest głównie spadek produktywności. Tak się stało w UK, Nowej Zelandii i Australii. Jeśli spadnie produktywność, jedynym sposobem na zwiększenie konkurencji będzie obniżka płac. Taka perspektywa nie wróży dobrze europejskiej integracji. Populistyczna i antyeuropejska fala, jaka przeszła przez Europę w latach 2016-2017, nie opadła na zawsze. Referendum w Wielkiej Brytanii w 2016 r. oraz wybory do włoskiego parlamentu w marcu 2018 r. pokazały, że peryferie mogą odzyskać nie tylko głos, lecz także siłę.

\section{BIBLIOGRAFIA}

Bernanke B., The Great Moderation, mowa wygłoszona na spotkaniu Eastern Economics Association, Waszyngton, 20 II 2004.

Blanchard O., The State of Macro, „Annual Review of Economics” 2008, vol 1, nr 1, [online] https://doi.org/10.3386/w14259.

61 W. Streeck, Why the Euro Divides Europe, „New Left Review” 2015, nr 95, s. 21-22.

62 W. Streeck, L. Elsässer, Monetary Disunion. The Domestic Politics of Euroland, „MPIfG Discussion Paper" 2014, nr 14/17.

63 H. Patomäki, The Great Eurozone Disaster. From Crisis to Global New Deal, przel. J. O'Connor, London-New York 2013, s. 57-81.

64 F.W. Scharpf, Political Legitimacy in a Non-opitmal Currency Area, „MPIfG Discussion Paper” 2013, nr 13/15; tenże, No Exit from the Euro-Rescuing Trap?, „MPIfG Discussion Paper” 2014, nr 14/4; tenże, Forced Structural Convergence in the Eurozone - Or a Differentiated European Monetary Community, „MPIfG Discussion Paper” 2016, nr 16/15. 
Brunnermeier M.K., James H., Landau J.-P., The Euro and the Battle of Ideas, Princeton 2016.

Buiter W., The Unfortunate Uselessness of Most "State of the Art" Academic Monetary Economics, VoxEU, Research-based policy analysis and commentary from leading economists, 6 III 2009, [online] https://ssrn.com/abstract $=2492949$.

Clancy E., The Future of the Eurozone, European United Left/Nordic Green Left (GUE/NGL), 2017.

Constancio V., The European Crisis and the Role of the Financial System, mowa wygłoszona na konferencji „The crisis in the euro area”, Ateny, 23 V 2013, [online] https://www.ecb.europa.eu/press/key/date/2013/html/sp130523_1.en.html.

Directorate General for Internal Policies, Policy Department C: Citizen's Rights and Constitutional Affairs, Article 136 TFEU, ESM, Fiscal Stability Treaty Ratification requirements and present situation in the Member States, 2013, [online] http://www.europarl. europa.eu/meetdocs/2009_2014/documents/afco/dv/2013-06-12_pe462455-v16_/ 2013-06-12_pe462455-v16_en.pdf.

European Commission, Communication from The Commission to The European Parliament, The Council, The European Economic and Social Committee and the Committee of the Regions towards a Positive Fiscal Stance for the Euro Area, 2016, [online] https://ec.europa.eu/info/ sites/info/files/2017-european-semester-communication-fiscal-stance_en_1.pdf.

European Commission, Report of the Study Group on the Role of Public Finance [Raport MacDougalla], Brussels 1977, [online] http://ec.europa.eu/archives/emu_history/documentation/chapter8/19770401en73macdougallrepvol1.pdf.

European Commission, Report to the Council and the Commission on the Realization by Stages of Economic and Monetary Union in the Community [Raport Wernera], Luxembourg 1970, [online] http://ec.europa.eu/economy_finance/publications/pages/publication6142_en.pdf.

Friedman M., The Euro: Monetary Unity to Political Disunity?, „Project Syndicate” 1997, 28 IX, [online] https://www.project-syndicate.org/commentary/the-euro--monetary-unityto-political-disunity.

The Future of the Euro, red. M. Matthijs, M. Blyth, New York 2015.

The Good, the Bad, and the Ugly: 100 Years Dealing with Public Debt Overhang, „IMF World Economic Outlook", X 2012.

Grauwe P. de, The Limits of the Market. The Pendulum between Government and Market, przel. A. Asbury, Oxford 2017.

Grauwe P. de, Ji Y., Panick-Driven Austerity in the Eurozone and Its Implications, VOX CEPR's Policy Portal, 21 II 2013, [online] https://voxeu.org/article/panic-drivenausterity-eurozone-and-its-implications.

Halligan L., Chronicle of a Disaster Foretold Plays Out on the Streets of Athens, „The Daily Telegraph" 2010, $1 \mathrm{~V}$, [online] https://www.telegraph.co.uk/finance/comment/7664328/ Chronicle-of-a-disaster-foretold-plays-out-on-the-streets-of-Athens.html.

Harndon T., Ash M., Pollin R., Does Public Debt Consistently Stifle Economic Growth? A Critique of Reinhart and Rogoff, „PERI Working Paper” 2013, nr 332.

Hayek F.A., The Economic Conditions of Interstate Federalism, [w:] Individualism and Economic Order, red. F.A. Hayek, Chicago 1948.

Hinarejos A., The Euro Area Crisis in Constitutional Perspective, Oxford 2015. 
Hopkin J., The Troubled Southern Periphery: The Euro Experience in Italy and Spain, [w:] The Future of the Euro, red. M. Matthijs, M. Blyth, New York 2015.

Jacoby W., Europe's New German Problem: The Timing of Politics and the Politics of Timing, [w:]

The Future of the Euro, red. M. Matthijs, M. Blyth, New York 2015.

Jourdan S., Unprecedented Coalition of MEPs against The ECB's Lack of Transparency, 2 VI 2017, [online] http://www.qe4people.eu/mario_draghi_dodges_transparency_eu_parliament.

Kawalec S., Pytlarczyk E., Paradoks euro. Jak wyjść z putapki wspólnej waluty?, Warszawa 2016.

Lapavitsas C. [i in.], Crisis in the Eurozone, London-New York 2012.

Lucas R. Jr., Macroeconomic Priorities, „American Economic Review” 2003, vol. 93, nr 1, [online] https://doi.org/10.1257/000282803321455133.

Marsch D., The Euro. The Battle for the New Global Currency, Yale 2011.

Marsch D., Europe's Deadlock. How the Euro Crisis Could be Solved - and Why It Won't Happen, Yale 2013.

Matthijs M., Blyth M., Introduction: The Future of the Euro and the Politics of Embedded Currency Areas, [w:] The Future of the Euro, red. M. Matthijs, M. Blyth, New York 2015.

Meiers F.-J., Germany's Role in the Euro Crisis. Berlin's Quest for a More Perfect Monetary Union, New York 2015.

Mitchell W., Eurozone Dystopia. Groupthink and Denial on a Grand Scale, Cheltenham-Northampton 2015.

Mitchell W., Fazi T., Reclaiming the State. A Progressive Vision of Sovereignty for a Post-Neoliberal World, London 2017.

Monetary Union in Crisis. The European Union as Neo-Liberal Construction, red. B.H. Moss, Houndmills-New York 2004.

Newman A., The Reluctant Leader: Germany's Euro Experience and the Long Shadow of Reunification, [w:] The Future of the Euro, red. M. Matthijs, M. Blyth, New York 2015.

One Market, One Money. An Evaluation of the Potential Benefits and Costs of Forming an Economic and Monetary Union, „European Economy” 1990, nr 44, [online] http://ec.europa.eu/ economy_finance/publications/pages/publication7454_en.pdf.

Patomäki H., The Great Eurozone Disaster. From Crisis to Global New Deal, przeł. J. O'Connor, London-New York 2012.

Posner M., Sir Donald MacDougall. Government Economic Adviser from Churchill to Heath, „The Guardian” 2004, 25 III, [online] https://www.theguardian.com/news/2004/mar/25/ guardianobituaries.obituaries.

Rajan R.G., Fault Lines. How Hidden Fractures still Threaten The World Economy, Princeton 2010.

Rehn O., Debt, Governance and Growth: A Euro Area Perspective, 2011, [online] http://europa. eu/rapid/press-release_SPEECH-11-407_en.htm.

Reinhart C.M., Rogoff K.S., Growth in a Time of Debt, „NBER Working Paper” 2010, nr 15639 , [online] http://www.nber.org/papers/w15639, http://doi.org/10.3386/w15639.

Romer P., The Trouble with Macroeconomics, Commons Memorial Lecture of the Omicron Delta Epsilon Society, New York University, 5 I 2016.

Scharpf F.W., Forced Structural Convergence in the Eurozone - Or a Differentiated European Monetary Community, „MPIfG Discussion Paper” 2016, nr 16/15. 
Scharpf F.W., No Exit from the Euro-Rescuing Trap?, „MPIfG Discussion Paper” 2014, nr 14/4.

Scharpf F.W., Political Legitimacy in a Non-optimal Currency Area, „MPIfG Discussion Paper” 2013, nr 13/15.

Schmidt V.A., The Forgotten Problem of Democratic Legitimacy: "Governing by the Rules" and "Ruling by the Numbers", [w:] The Future of the Euro, red. M. Matthijs, M. Blyth, New York 2015.

Smith T.B., France in Crisis, Welfare, Inequality, and Globalization since 1980, Cambridge-New York 2004.

Stable Money - Sound Finances. Community Public Finance in the Perspective of EMU, „European Economy" 1993, nr 53, [online] http://ec.europa.eu/economy_finance/publications/ pages/publication7524_en.pdf.

Streeck W., Elsässer L., Monetary Disunion. The Domestic Politics of Euroland, „MPIfG Discussion Paper” 2014, nr 14/17.

Streeck W., Why the Euro Divides Europe, „New Left Review” 2015, nr 95.

Sverker G., What Makes a European Monetary Union without a Parallel Fiscal Union Politically Sustainable?, [w:] Political Aspects of the Economic and Monetary Union. The European Challenge, red. S. Dosenrode, Aldershot-Burlington 2002.

Szef EBC Mario Draghi pod presja oczekiwań, „Forbes” 2012, 3 IX, [online] https://www.forbes.pl/wiadomosci/szef-ebc-mario-draghi-pod-presja-oczekiwan/00d6qgp.

Vines D., Wills S., Rebuilding Macroeconomic Theory, „Oxford Review of Economic Policy” 2018, vol. 34, nr 1-2, [online] https://doi.org/10.1093/oxrep/grx062.

Wolf M., Economics Failed Us Before the Global crisis, „The Financial Times” 2018, 20 III, [online] https://www.ft.com/content/28e2f9ac-2b66-11e8-9b4b-bc4b9f08f381.

Wyplosz Ch., European Monetary Union: The Dark Sides of a Major Success, „Economic Policy” 2006, vol. 21, nr 46, [online] https://doi.org/10.1111/j.1468-0327.2006.00158.x.

Dr Marcin GALENT, adiunkt w Instytucie Europeistyki Uniwersytetu Jagiellońskiego. Jest doktorem socjologii i prowadzi kursy na temat kondycji państwa dobrobytu w Europie, współczesnej Wielkiej Brytanii oraz migracji, obywatelstwa i wielokulturowości w Europie. Autor ponad 40 publikacji naukowych. 